\title{
Registration of Chercher and Haramaya: Common Bean Varieties for Production in Eastern Ethiopia
}

\author{
Chemeda Fininsa* and Bulti Tesso
}

Department of Plant Sciences, Haramaya University, P O Box 138, Dire Dawa, Ethiopia

\begin{abstract}
Two common bean (Phaselus vulgaris L.) varieties: Chercher (STTT-165-96) and Haramaya (G-843) developed by the Haramaya University were released for production in the highlands of Hararghe and similar agro-ecologies in 2005 and 2006, respectively. These varieties were selected and evaluated at 12 environments (locations x years) in eastern Ethiopia between 1998 and 2001. The varieties were described in their phenological and seed characters, yield performance, disease reaction, quality aspect, and adaptation, and compared with the standard and local checks. The varieties have indeterminate bush type growth habit and preferable seed size and color, stable and high yield (1.7 tons ha ${ }^{-1}$ for Chercher and 2.8 tons ha $^{-1}$ for Haramaya) across environments, resistance reactions to major fungal and bacterial diseases, and superior canning (Chercher) and food qualities.
\end{abstract}

Keyword: Chercher; Common Bean; Haramaya; Variety Registration

\section{Introduction}

Chercher (STTT-165-96) and Haramaya (G-843) are common bean (Phaseolus vulgaris $L$.) varieties released in 2005 and 2006 respectively, by the Haramaya University (HU). Chercher is navy (white) bean type. They were among CIAT/ECABREN breeding lines that had been introduced to Ethiopia and evaluated in preliminary observation nurseries in 1996 and advanced observation nurseries in 1997 at Haramaya Research Center. The official release of the varieties to bean producing areas in eastern and western Hararghe was approved by the Ethiopian National Variety Release Committee in accordance with the national variety release and registration policy of the country. Breeder and foundation seed is maintained by HU. In describing these varieties, descriptions of new common bean varieties used by Grafton et al. (1993), Kelly et al. (1994) and Saindom et al. (1996) were adopted.

\section{Evaluation}

Chercher and Haramaya were tested under Regional Variety Trial at 12 environments (locations x years) in eastern Ethiopia between the years 1998 and 2001. Chercher was evaluated along with Mexican-142 (G11239) and Awash-1 (Extrico-23) as standard checks. On-farm evaluation was conducted during 2004 at 10 sites, with Melka Awash-98 (PAN-182) as new standard check at altitudes ranging from 1650-2200 meter above sea level.

Haramaya was evaluated along with Roba-1 (A-176) as standard and Red Wolaita as local checks. On-farm evaluation was conducted during 2005 at 8 sites with Zebra (GX-1175-3) as the new standard check. The sites represent common bean production environment with altitude range of 1700-2200 meters above sea level.

\section{Varieties Characters}

Chercher is a tall and an erect variety of an indeterminate bush (type IIa) growth habit. It has thick stem and branches, with vigorous up right growth, thus resistant to lodging. The canopy height ranges from 36$50 \mathrm{~cm}$ depending on the environment. The average days-to-flowering after emergence is 52 and maturity is 105 days (Table 1). On average, it produces 25 pods per plant. The pods are straight and nearly round in shape; medium in size with average dimensions of length $(9 \mathrm{~cm})$, width $(9.4 \mathrm{~mm})$, and thickness $(6.8 \mathrm{~mm})$ at maturity. The variety on average produces 5 seeds per pod. The seeds are white (navy types) and nearly elliptical, with dimensions of length $(10 \mathrm{~mm})$, width $(6.5 \mathrm{~mm})$, and thickness $(5.3 \mathrm{~mm})$. The average weight of 100 -seeds is $20.4 \mathrm{~g}$, which is greater by $20 \%$ than that of Melka Awash- 98.

Haramaya is characterized by its indeterminate prostrate (type IIIb) growth habit. The variety flowers 52 days after emergence and matures in 99 days (Table 1). The pods are green before maturity, are round in shape and of medium size. Each pod produces on average 4 seeds.The seeds belong to the cream (mulatinho) market class, with a prominent yellow color of the hillary ring. The plump, shiny seeds on average weigh $33 \mathrm{~g}$ per 100 -seeds, which is greater by $83 \%, 74 \%$ and $14 \%$ than those of Roba-1, Red Wolaita, and Zebra, respectively.

\section{Yield Performance}

Chercher has shown superior yield performance across environments (2-3 tons $\left.\mathrm{ha}^{-1}\right)$ without fertilization; exceeding Awash-1 by $30 \%$ and Mexican-142 by $10 \%$ but similar with Melka-Awash 98. It gave a maximum yield of 3.3 tons ha $^{-1}$ at one location (average of 3 years), which indicated its increasing response to potential environments receiving adequate rainfall and having fertile soils.

Hararmaya is well adapted to the environments in 
eastern Ethiopia receiving a well distributed average annul rainfall of greater than $650 \mathrm{~mm}$. Grain yield ranged between 1.7 tons $\mathrm{ha}^{-1}$ at low rainfall receiving areas and 3.8 tons $\mathrm{ha}^{-1}$ at areas receiving high rainfall and having fertile soils without fertilization. The average yield is 2.8 tons ha $^{-1}$, exceeding Roba- 1 by $50 \%$ and Red Wolaita by $48 \%$. On-farmers' fields higher yield advantages of $71 \%, 41 \%$, and $15 \%$ over Roba-1, Red Wolaita, and Zebra, respectively, have been recorded.

\section{Reaction to Diseases}

On the standard rating scale of $1-9,1$ being highly resistant and 9 highly susceptible, Chercher scored a mean of 2 for bean rust (Uromyces appendiculatus), angular leaf spot (Phaeoisariopsis griseola) and halo blight (Pseudomonas syringae pv. phaseolicola), and 3 for anthracnose (Colletotricum lindemuthianum) and common bacterial blight (Xanthomonas campestris $p v$. phaseoli) (Table 1). Haramaya scored 1 for angular leaf spot and anthracnose, 2 for halo blight and rust, and 3 for common bacterial blight (Table 2). The varieties are resistant to the major common bean diseases. The resistance reaction of the varieties could be integrated with other disease management methods such as seed treatment, growing in intercropping, and managing infested debris.

Table 1. Mean agronomic characters and disease reactions of Chercher (STTT-165-96), Haramaya (G-843) and their check varieties in multilocation trial

\begin{tabular}{|c|c|c|c|c|c|c|c|c|}
\hline \multirow[t]{2}{*}{ Variety } & \multicolumn{3}{|c|}{ Agronomic character } & \multicolumn{5}{|c|}{ Disease reaction } \\
\hline & $\mathrm{DF}$ & DM & $\mathrm{YI}\left(\mathrm{tha}^{-1}\right)$ & $\mathrm{RU}$ & ANT & ALS & HB & CBB \\
\hline Chercher & 52 & 105 & 1.7 & 2.3 & 2.7 & 1.7 & 1.9 & 3.5 \\
\hline Mexican-142 $2^{2}$ & 56 & 108 & 1.5 & 5.0 & 2.8 & 1.3 & 2.2 & 3.7 \\
\hline Awash- $1^{2}$ & 56 & 108 & 1.3 & 2.3 & 2.8 & 2.0 & 1.9 & 3.4 \\
\hline Haramaya & 52 & 99 & 2.8 & 2.0 & 1.3 & 1.0 & 1.6 & 2.8 \\
\hline Roba- $1^{3}$ & 58 & 102 & 1.4 & 1.3 & 1.6 & 1.0 & 2.0 & 2.6 \\
\hline Red Wolaita ${ }^{3}$ & 54 & 102 & 1.4 & 4.0 & 4.0 & 1.3 & 2.3 & 4.0 \\
\hline
\end{tabular}

${ }^{T}$ Disease score based on 1-9 scale where 1 is highly resistant and 9 is highly susceptible.

$D F=$ days to flowering; $D M=$ days to maturity; $Y I=$ yield; $R U=$ rust; $A N T=$ anthracnose; $A L S=$ angular leaf

spot; $H B=$ halo blight; $C B B=$ common bacterial blight

${ }^{2}$ check varieties for Chercher.

${ }^{3}$ check varieties for Haramaya.

\section{Quality Test}

Canning quality test conducted at Lodato Gennaro and C.S.P.A Industrie Conserve Alimentari, Italy indicated that Chercher was the best in its canning quality, being the lightest in processed bean color and the softest in firmness, compared to the current Melka Awash-98, the standard check. In a quality test conducted at HU food science laboratory, Chercher was found fast soaked with $100 \%$ soakability and 2.1 hydration index compared to $89 \%$ soakability and 1.9 hydration index for Melka Awash-98. Average crude protein and ash contents of Chercher raw dry seeds are $25.7 \%$ and $4.7 \%$, respectively, which is about the same with the standard variety.

Haramaya is preferred by producers and consumers for its attractive seed physical characteristics (color, size, shape and plumpness). It is also preferred for its suitability for preparing different local dishes (in the form of boiled grain, shummo) and for sauce making. Haramaya was found $100 \%$ soakable with mean cooking time of 30 minutes.

\section{Adaptation}

Chercher and Haramaya are released for production in eastern and western Hararghe, eastern Ethiopia, preferably for areas receiving a well distributed total annual rainfall of greater than $650 \mathrm{~mm}$. However, the varieties can be extended to other regions of similar agro-ecologies after adaptation trials. The upright growth habit and good pod clearance character of Chercher would make it suitable for production under intercropping and irrigation in all potential regions of
Ethiopia. On highly fertile soils with relatively better rainfall receiving, Haramaya often shows excessive vegetative growth, and needs a wider spacing than the recommended $40 \mathrm{~cm}$ inter-row and $10 \mathrm{~cm}$ inter-plant spacing. Depending on fertility and cropping system (sole cropping versus intercropping) seed rate of 50-60 $\mathrm{kg} \mathrm{ha}^{-1}$ could be used. The varieties can be planted in early April in spring season, Belg and in early July in summer season, Meher.

\section{Acknowledgements}

HU, EIAR, and CIAT/ECABREN offered financial support to develop the varieties. Frew Mekbib, Abdulrazak Yusuf, Meklit Tariku, and Zenebe Gebremedhin coordinated the Common Bean Research at HU during the early phases of the varieties' selection. We acknowledge Wetatu Welebo, Woinshet Feleke, Seife Lemma, Demeke Ejigu and Ibssa Ali for their assistance in field data collection.

\section{References}

Grafton, K.F., Chang, K.C., Venette, J.R., Wal, A.J. and Vander, 1993. Registration of 'Norstar' navy bean. Crop Science 33: 1405-1406.

Kelly, J.D., Hostfield, G.L., Varner, G.V., Uebersax, M.A., Brothers, M.E. and Taylor, J. 1994. Registration of 'Huron' navy bean. Crop Science 34: 1408 .

Saindom, G. Mundel, H.H. and Huang, H.C. 1996. Registration of 'AC Skipper'navy bean. Crop Science 36: 207 
